\title{
EFFECT OF MINERAL NUTRITION ON NUT YIELD AND FRUIT COMPOSITION OF MATURE COCONUT PALMS IN THE COASTAL BELT OF WESTERN REGION OF GHANA - PRELIMINARY STUDIES
}

\author{
E. Andoh-Mensah ${ }^{1}$, X. Bonneau ${ }^{2}$, B.N. Nuertey ${ }^{3}$, and, S.K. Dery ${ }^{1}$
}

\begin{abstract}
The nut yield and fruit composition of mature (30-40 years old) West African Tall coconut palms were evaluated in seven trials during the first three years (from June 2000 to May 2003) of implementation of a five-year fertilization schedule recommended to the Coconut Sector Development Project (CSDP) for the rehabilitation of old farms in the coastal belt of the Western Region of Ghana. The seven trials are located at Jeway Wharf, Takinta, Ellenda, Nawule, AB Bokazo, Anwia and Edwakpole. Three fertilizer treatments were applied between June 2000 and May 2003. The first two fertilizers were applied in June 2000 and May 2001 at the rate of $0.75 \mathrm{~kg}$ urea and $2.5 \mathrm{~kg}$ muriate of potash (MOP) per palm. For the third fertilization, $1 \mathrm{~kg}$ MOP only was applied per palm in May 2002. Fertilizer treatment did not affect nut yield in year one of fertilization. But in year two, the fertilized plots gained remarkably 27.7, 20.2, 19.4 and 14.9 nuts per palm at Jeway Wharf, Nawule, Ellenda and Takinta respectively. The remarkable nut gain was further boosted or sustained in year three except at Jeway wharf which lost 9.8 nuts per palm. In economic terms, Ellenda trial broke even on MOP fertilizer investment in year three while Jeway Wharf was close to breaking even. Takinta and Nawule trials made profits of 925 and 1,750 cedis (3.7 and 7 nuts) per palm respectively in year three. For Anwia, AB Bokazo and Edwakpole trials there was no yield response to MOP fertilizer due to $P$ deficiency. Fertilizer treatment in the first two years of fertilization did not influence fruit composition.
\end{abstract}

\section{INTRODUCTION}

Apart from the devastating threat posed by the Cape Saint Paul Wilt Disease (CSPWD) (Dery et al., 1995), the coconut industry in Ghana is beset with low yield estimated at 5000 nuts per hectare per year (Ofori and Nkansah-Poku, 1995) in spite of its production potential of 15,000 nuts per hectare per year (90 nuts per tree per year) (Dery et al., 1999). This may be attributed to poor nutrition and lack of farm maintenance (Ofori and Nkansah-Poku, 1995). 
In 1997, a project feasibility study by a CIRAD (Centre de Coopération Internationale en Recherche Agronomique pour le Développement) consultant observed that there were marked nutritional deficiencies in the mature coconut plantations of the coastal belt of the Western Region (Dery et al., 1999). Analysis of leaf samples taken from coconut palms in 1998 confirmed the poor nutritional status of the plantations. The leaf potassium $(\mathrm{K})$ was very low with a mean value of $0.42 \%$ for a reference level of $0.8 \%$ in the West African Tall, with some extremely low individual values $(0.196 \%$ at Half Assini near Jeway Wharf for instance). The leaf nitrogen $(\mathrm{N})$, which seemed to be quite high, was possibly an indication of low mobilization of $\mathrm{N}$ reserve in the coconut trees due to $\mathrm{K}$ deficiency (Dery et al., 1999).

The deficiency evidence and the attendant low yields, established the need for restoration of nutritional status of the coconut trees of the coastal belt to increase nut production. A five-year fertilization schedule (Table. 1) was recommended to the Coconut Sector Development Project (CSDP) for the rehabilitation of old farms not yet affected by the lethal yellowing disease. Consequently, field trials were initiated to validate and fine-tune the recommendations to ensure optimum nut production. The objective of this study is to evaluate the nut yield and fruit composition of the trials in the first three years of implementation of the five - year fertilization schedule.

\section{MATERIALS AND METHODS}

The study was conducted in the coastal belt of the Western Region of Ghana from June 2000 to May 2003 on seven mature coconut farms located at Jeway Wharf, Takinta, Ellenda, Nawule,
AB Bokazo, Anwia and Edwakpole, between Ankobra river and border with Côte

d'Ivoire (see map). The coconut trees of the trials were West African Tall variety planted at irregular spacing (farmer's own spacing) and aged between 30-40 years.

Two treatments: $A=$ farmer's own upkeep without mineral fertilization (control) and $\mathrm{B}=$ mineral fertilization + ring weeding + regular slashing of natural regrowth were evaluated. The two treatments were arranged in a randomized complete block design with 13 replications. Each trial was composed of 4 unit plots representing two replicates of treatments $\mathrm{A}(\mathrm{A} 1$ and $\mathrm{A} 2)$ and $\mathrm{B}$ (B1 and B2). At Takinta however, the trial was composed of two unit plots. Each plot contained 48 palms comprising of 24 useful palms and 24 border palms. The slashing of natural regrowth of treatment A plots from June 2000 to May 2003 varied from 3 to 4 times according to the site. Treatment B plots were slashed 7 times and were given three fertilizer treatments over the same period. The first two fertilizers were applied in June 2000 and May 2001 at the rate of $0.75 \mathrm{~kg}$ urea and $2.5 \mathrm{~kg}$ muriate of potash (MOP) per palm. For the third fertilization, $1 \mathrm{~kg}$ MOP only was applied per palm in May 2002. Mean of 4 composite soil samples per site were taken at two horizons: 0 $20 \mathrm{~cm}$ and $20-40 \mathrm{~cm}$ from the control plots in October 2002 for analysis. Leaf analysis was carried out annually in May to determine the nutritional status of the palms. Leaf number 14 of useful trees was sampled for analysis. Nut count and fruit component analysis were done twice per year in May and November. Nuts in the bunch of leaf ranks 14, 19 and 24 were counted separately and averaged. The mean number of nuts was multiplied by 12 months to estimate annual nut load per palm. Fruit component analysis was carried out on a mean of 48 dry nuts per plot ( 2 nuts per useful tree) by determining the precise weights of the various components of the dry coconut fruit. Data were statistically analyzed.

\section{RESULTS}

\subsection{Leaf analysis}

In the fertilized plots (treatment B), there were significant $(\mathrm{P}<0.05)$ increases in leaf $\mathrm{N}$ and $\mathrm{K}$. However, increase in $\mathrm{N}$ was not as remarkable as 
$\mathrm{K}$, which ranged from $48 \%$ at Anwia to $197 \%$ at Nawule (Table 2). The leaf phosphorus (P) observed at Jeway Wharf, Takinta, Ellenda and Nawule (mean of $0.138 \%$ ) were significantly $(\mathrm{P}<0.05)$ higher than the level of leaf $\mathrm{P}$ at $\mathrm{AB}$ Bokazo, Anwia and Edwakpole (mean of 0.107\%).

\subsection{Soil analysis}

Soils at the 7 sites were acidic with $\mathrm{pH}$ ranging from 4.9 - 5.9, low in organic matter (less than $2 \%$ ) and located on sandy soils except at Anwia where the soil was loamy with acceptable level of organic matter (around 3\%). Table 3 shows extreme soil $\mathrm{P}$ deficiency at Anwia, AB Bokazo and Edwakpole and very low soil $\mathrm{K}$ at all the sites. Soil $\mathrm{N}$ however, was at satisfactory level in all the 7 trials.

\subsection{Nut production}

Nut loads in the fertilized plots were not significantly $(\mathrm{P}<0.05)$ different from the unfertilized plots in year one. But in year two and three, significant increases were observed (Table.4). While a general decline (mean loss of 5.2 nuts per palm) was observed in the unfertilized plots in year two, the fertilized plots gained remarkably $27.7,20.2,19.4$ and 14.9 nuts per palm at Jeway Wharf, Nawule, Ellenda and Takinta respectively. In year three, the nut gain per palm was sustained at 19.4 in Ellenda. But at Takinta and Nawule the nut gain was further boosted to 22.7 and 26.0 per palm respectively. In Jeway
The composition of dry nuts from fertilized plots in April 2002, two years after treatment has begun, were not significantly $(\mathrm{P}<0.05)$ different from that of the unfertilized plots as illustrated by meat and water weight per nut (Table 5).

\subsection{Cost efficiency of fertilization}

Cost of MOP per $\mathrm{kg}$ is 2600 cedis. Transport of MOP per kg to farm-gate is 160 cedis. Labour for application of MOP per $\mathrm{kg}$ is 150 cedis. Therefore, total cost of fertilization per $\mathrm{kg}$ is 2910 cedis. Current farm-gate sale price per nut ranges from 200 - 300 cedis depending on the marketing arrangement. Average sale price of 250 cedis per nut will be used in the calculation. The case of Nawule: estimating the effective increase in nut production based on the difference between the initial nut load in year one and nut load in subsequent years, and assuming the coconut trees in the trial attain their full potential of 90 nuts per tree per year (Dery et al., 1999) in year 4 and sustaining it for at least 2 years after the five-year fertilization schedule and considering the fact that fertilizer effect on nut load is observed in year two of fertilization, the following simulation is obtained:

A mean increase of 31 nuts per palm per year is obtained over a period of 6 years with an average application of $1.6 \mathrm{~kg}$ of MOP per palm per year.

In economic terms, fertilizer investment of

Simulation of MOP effect on nut yield in best conditions (Nawule model)

\begin{tabular}{|c|c|c|c|c|c|c|c|}
\hline Year & $\mathbf{1}$ & $\mathbf{2}$ & $\mathbf{3}$ & $\mathbf{4}$ & $\mathbf{5}$ & $\mathbf{6}$ & $\mathbf{7}$ \\
\hline $\begin{array}{c}\text { MOP application } \\
(\mathrm{kg} / \mathrm{palm})\end{array}$ & 2.5 & 2.5 & 1 & 1 & 1 & 0 & 0 \\
\hline $\begin{array}{c}\text { Effective increase in } \\
\text { nuts per palm }\end{array}$ & 0 & 20.2 & 26.0 & 34.9 & 34.9 & 34.9 & 34.9 \\
\hline
\end{tabular}

Wharf, while the unfertilized plot gained 17.3 more nuts per palm in year three, the fertilized plot lost 9.8 nuts per palm. For Anwia, AB Bokazo and Edwakpole there was no yield response to fertilizer treatment over the period.

\subsection{Fruit composition}

$1.6 \times 2190=4,656$ cedis per palm per year is followed by nut yield benefit of $31 \times 250=7,750$ cedis per palm per year. Thus, a profit: cost ratio of 7,750/4,656 $=1.66$ is obtained. Nut increase per palm per year required to recover fertilizer investment is given by $4,656 / 250=18.624$, thus it takes an increase of at least 19 nuts per palm per year to recover the investment made on MOP 
fertilizer. It is beyond this threshold of +19 nuts per palm per year that the farmer made profit.

\section{DISCUSSION}

\subsection{Leaf and soil analysis}

There were significant increases in both $\mathrm{N}$ and $\mathrm{K}$ due to fertilizer treatment. However, the increase in $\mathrm{N}$ was not as remarkable as $\mathrm{K}$. This may be due to stimulation of rapid uptake of $\mathrm{K}$ by its initial low level in the leaf (mean of $0.53 \%$ for a reference value of $0.80 \%$, with extremely low initial $\mathrm{K}$ contents like in Jeway Wharf and Nawule) to ensure restoration of nutritional balance (Dery et al, 1999). The initial low leaf K could be attributed to low level of $\mathrm{K}$ in the soil (mean of $0.04 \mathrm{meq} / 100 \mathrm{~g}$ in top-soil for a reference of $0.15-0.20 \mathrm{meq} / 100 \mathrm{~g}$ ) and to absence of fertilization and maintenance in the past. The leaf $\mathrm{N}$ however, compared with a reference value of $2.0 \%$, was at non-deficient level even before fertilization (Table.2). This was due to satisfactory level of initial soil $\mathrm{N}$ (mean of $0.66 \%$ in top-soil for a reference of $0.2-0.5 \%$ ). Leaf $\mathrm{P}$ observed at $\mathrm{AB}$ Bokazo, Anwia and Edwakpole (mean of $0.107 \%$ ) were below the reference value of $0.120 \%$. This was because the soil $\mathrm{P}$ was deficient at the three sites (Table.3). A high correlation $\left(\mathrm{r}^{2}=\right.$ 0.94) was observed between soil and leaf P (fig 1). Consequently, triple supperphosphate (TSP) was applied at the rate of $2.5 \mathrm{~kg}$ per palm at the three sites in October 2002 to rectify the P deficiency.

\subsection{Nut yield}

There was no significant difference between fertilized and unfertilized plots in terms of nut load in year one of fertilization. In year two however, the fertilized plots had significantly higher nut loads than the unfertilized plots except at $\mathrm{AB}$ Bokazo, Anwia and Edwakpole. This observation was confirmed in year three except at Jeway Wharf. The significant effect of fertilization on nut load from year two is in accordance with Bonneau et al., (2002). The inability of AB Bokazo, Anwia and Edwakpole plots to respond to fertilizer treatment in year two could be attributed to $\mathrm{P}$ limitation as leaf and soil $\mathrm{P}$ observed at the three sites were below the reference level. Wehrmann, (1976) observed that the level of yield response of plants to fertilizer treatment depends on the inherent nutritional content of the unfertilized soil.
It is worth trying to see if application of $\mathrm{P}$ fertilizer at these sites can lead to significant increase in nut load. The inability of the fertilized palms at Jeway Wharf to sustain the 27.7 nut gain per palm in year three might be attributed to difficulty in rehabilitating durably coconut palms, which have been under prolonged nutritional stress (Bonneau, pers. comm.).

\subsection{Fruit Composition}

The composition of dry nuts was not influenced significantly by two years of fertilizer treatment. There was large variability in fruit weight within plots due to lack of purity in the West African Tall variety (Owusu-Nipah, pers. comm.). Also, a strong pressure from mites (Aceria guerreonis) has a depressing effect on fruit size in all the trials, irrespective of fertilizer treatments. Therefore, the fertilizer effect on fruit composition will have to be remarkable for it to be detected.

\subsection{Cost efficiency of fertilization}

The estimated threshold of +19 nuts under the experimental conditions that prevailed in year three meant that Ellenda trial only broke even (recovered the MOP fertilizer investment cost without profit). However, Takinta and Nawule trials made profits of 925 and 1,750 cedis (3.7 and 7 nuts) per palm per year respectively on investment in MOP fertilizer. In Jeway Wharf, the trial was close to breaking even. At AB Bokazo, Anwia and Edwakpole it was a bad investment applying only MOP fertilizer due to $\mathrm{P}$ deficiency which accompanied the $\mathrm{K}$ deficiency.

\section{CONCLUSION AND RECOMMENDATION}

Fertilizer treatment did not affect nut yield in year one of fertilization. But in year two, the fertilized plots gained remarkably 27.7, 20.2, 19.4 and 14.9 nuts per palm at Jeway Wharf, Nawule, Ellenda and Takinta respectively. The remarkable nut gain was further boosted or sustained in year three except at Jeway Wharf, which lost 9.8 nuts per palm. In economic terms, Ellenda trial broke even on MOP fertilizer investment in year three while Jeway Wharf was close to breaking even. Takinta and Nawule trials made profits of 925 and 1,750 cedis (3.7 and 7 nuts) per palm respectively 
in year three. For Anwia, $A B$ Bokazo and Edwakpole trials there were no yield response to MOP fertilizer due to $\mathrm{P}$ deficiency. Fertilizer treatment in the first two years of fertilization did not influence fruit composition.

Further work is necessary to prepare a soil fertility/deficiency map of the coastal belt of the Western Region to provide useful basis for recommendation of appropriate fertilizers to meet specific needs of the coconut farmers in the region.

\section{ACKNOWLEDGEMENT}

The authors wish to acknowledge that Agence Francaise de Developpement financed this study under the Coconut Sector Development Project with Ghana Rubber Estates limited as the project operator.

\section{REFERENCES}

Ofori, F. and Nkansah-Poku J. (1995). Cape Saint Paul Wilt Disease of Coconut in Ghana. History of its occurrence and spread In: S. J. Eden Green and F. Ofori (Eds), Proceedings of an International Workshop on Lethal Yellowing like Disease of Coconut, Elimina, Ghana, November 1995, Chatman, UK, Natural Resources Institute, pp. 27 - 32.

Dery, S. K., N'cho Y. P., Sangaré A and Arkhurst E. D. (1995). Cape St. Paul Wilt Disease: Resistance Screening and Prospects for Rehabilitating the Coconut Industry in Ghana. In: S. J. Eden Green and F. Ofori (Eds), Proceedings of an International Workshop on Lethal Yellowing-Like Disease of Coconut, Elimina, Ghana, November 1995, Chatman, UK, Natural Resources Institute, pp 147 - 151.

Dery, S. K., Philippe R. and Calvez C. H. (1999). Coconut Sector Development Project: Report on Applied Research Programme in
Agronomy and Crop Protection to the operator of the Project (GREL), May 1999, pp. 26-28.

Bonneau, X., Dery, S. K and Andoh-Mensah E. (2002). Coconut Sector Development Project, Report on the mission from 21st April to 5th May 2002. CIRAD-CP Doc. CPSIC 1497, Montpellier, France pp. 21-22

Wehrmann, J. (1976). Possibilities and limits of Intensive fertilization. In: Plant Research and Development. Vol 3. Institute of scientific co-operation, Turbingen, Federal Republic of Germany, pp. 101 - 122 
Table 1: Five-year fertilization schedule recommended for rehabilitation of mature coconut farms in the coastal belt of the Western Region

\begin{tabular}{cccccc}
\hline Year & $\mathbf{1}$ & $\mathbf{2}$ & $\mathbf{3}$ & $\mathbf{4}$ & $\mathbf{5}$ \\
\hline $\begin{array}{c}\text { Urea } \\
(\mathrm{kg} / \mathrm{palm})\end{array}$ & 0.75 & 0.75 & 0 & 0 & 0 \\
$\begin{array}{c}\text { MOP } \\
(\mathrm{kg} / \mathrm{palm})\end{array}$ & 2.5 & 2.5 & 1.0 & 1.0 & 1.0 \\
\hline
\end{tabular}

Table 2: Leaf $N, P$ and $K$ contents averaged over two years May 2001 and 2002

\begin{tabular}{lcccc}
\hline \multicolumn{1}{c}{ Site } & Plot & N\% & P\% & K\% \\
\hline Jeway Wharf & $\mathrm{A}$ & 1.93 & 0.137 & 0.352 \\
& $\mathrm{~B}$ & 2.02 & 0.142 & 0.708 \\
Takinta & $\mathrm{A}$ & 2.12 & 0.148 & 0.512 \\
& $\mathrm{~B}$ & 2.18 & 0.142 & 0.835 \\
Ellenda & $\mathrm{A}$ & 2.22 & 0.149 & 0.571 \\
& $\mathrm{~B}$ & 2.18 & 0.132 & 0.952 \\
Nawule & $\mathrm{A}$ & 1.97 & 0.132 & 0.240 \\
& $\mathrm{~B}$ & 2.00 & 0.124 & 0.713 \\
AB Bokazo & $\mathrm{A}$ & 1.95 & 0.101 & 0.397 \\
\multirow{2}{*}{ Anwia } & $\mathrm{B}$ & 2.01 & 0.104 & 0.861 \\
& $\mathrm{~A}$ & 2.01 & 0.112 & 1.080 \\
Edwakpole & $\mathrm{B}$ & 2.18 & 0.109 & 1.595 \\
& $\mathrm{~A}$ & 1.99 & 0.106 & 0.535 \\
\multicolumn{1}{c}{ Mean } & $\mathrm{B}$ & 2.08 & 0.111 & 0.971 \\
\hline & $\mathbf{A}$ & $\mathbf{2 . 0 3}$ & $\mathbf{0 . 1 2 6}$ & $\mathbf{0 . 5 2 7}$ \\
& $\mathbf{B}$ & $\mathbf{2 . 0 9}$ & $\mathbf{0 . 1 2 3}$ & $\mathbf{0 . 9 4 8}$ \\
\hline
\end{tabular}


Table 3: Some chemical properties of the soil at the 7 sites in October 2002

\begin{tabular}{|c|c|c|c|c|}
\hline Site & $\begin{array}{c}\begin{array}{c}\text { Soil horizon } \\
(\mathbf{c m})\end{array} \\
\end{array}$ & $\begin{array}{c}\text { Total N } \\
\% \\
\end{array}$ & $\begin{array}{c}\text { Assimilable P } \\
\text { Olse Dabin ppm }\end{array}$ & $\begin{array}{l}\text { K exch. } \\
\text { meq/100g }\end{array}$ \\
\hline \multirow[t]{2}{*}{ Jeway Wharf } & $0-20$ & 0.47 & 22.6 & 0.03 \\
\hline & $20-40$ & 0.32 & 18.6 & 0.03 \\
\hline \multirow[t]{2}{*}{ Takinta } & $0-20$ & 0.49 & 19.8 & 0.03 \\
\hline & $20-40$ & 0.42 & 22.1 & 0.03 \\
\hline \multirow[t]{2}{*}{ Ellenda } & $0-20$ & 0.59 & 22.9 & 0.04 \\
\hline & $20-40$ & 0.46 & 22.5 & 0.03 \\
\hline \multirow[t]{2}{*}{ Nawule } & $0-20$ & 0.40 & 12.9 & 0.03 \\
\hline & $20-40$ & 0.35 & 12.5 & 0.02 \\
\hline \multirow[t]{2}{*}{ AB Bokazo } & $0-20$ & 0.57 & 3.2 & 0.04 \\
\hline & $20-40$ & 0.40 & 2.6 & 0.02 \\
\hline \multirow[t]{2}{*}{ Anwia } & $0-20$ & 1.30 & 4.3 & 0.07 \\
\hline & $20-40$ & 0.89 & 2.7 & 0.05 \\
\hline \multirow[t]{2}{*}{ Edwakpole } & $0-20$ & 0.77 & 2.7 & 0.05 \\
\hline & $20-40$ & 0.61 & 2.3 & 0.03 \\
\hline \multirow[t]{2}{*}{ Mean } & 0 - 20 & 0.66 & - & 0.04 \\
\hline & $20-40$ & 0.49 & - & 0.03 \\
\hline
\end{tabular}

Table 4: Nut load per palm per year in three years of fertilization

\begin{tabular}{|c|c|c|c|c|}
\hline \multirow{3}{*}{ Jeway Wharf } & $\bar{A}$ & 21.7 & 26.3 & 43.6 \\
\hline & B & 36.8 & 64.5 & 54.7 \\
\hline & A & 66.8 & 63.2 & 69.2 \\
\hline \multirow[t]{2}{*}{ Takinta } & B & 77.3 & 92.2 & 100.0 \\
\hline & A & 59.1 & 56.5 & 53.4 \\
\hline \multirow[t]{2}{*}{ Ellenda } & B & 65.5 & 84.9 & 84.9 \\
\hline & A & 31.3 & 26.4 & 33.7 \\
\hline \multirow[t]{2}{*}{ Nawule } & B & 55.1 & 75.3 & 81.1 \\
\hline & A & 53.3 & 41.7 & 49.6 \\
\hline \multirow[t]{2}{*}{ AB Bokazo } & B & 51.4 & 50.7 & 54.1 \\
\hline & A & 59.7 & 43.8 & 57.6 \\
\hline \multirow[t]{2}{*}{ Anwia } & B & 55.6 & 49.1 & 53.2 \\
\hline & A & 37.7 & 35.1 & 41.2 \\
\hline \multirow[t]{2}{*}{ Edwakpole } & B & 38.1 & 41.8 & 47.3 \\
\hline & $\mathbf{A}$ & 47.1 & 41.9 & 49.8 \\
\hline Mean & B & 54.3 & 65.5 & 67.9 \\
\hline $\mathbf{L S D}_{(0.05)}$ & & NS & 11.13 & 17.2 \\
\hline
\end{tabular}


Table 5: Meat and water weight per nut in April 2002

\begin{tabular}{|c|c|c|c|}
\hline Site & Plot & $\begin{array}{l}\text { Meat wt. } \\
\text { (g) }\end{array}$ & $\begin{array}{c}\text { Water wt. } \\
\text { (g) }\end{array}$ \\
\hline \multirow[t]{2}{*}{ Jeway Wharf } & $\bar{A}$ & 265 & 63 \\
\hline & B & 273 & 69 \\
\hline \multirow[t]{2}{*}{ Takinta } & A & 237 & 52 \\
\hline & B & 251 & 61 \\
\hline \multirow[t]{2}{*}{ Ellenda } & A & 241 & 63 \\
\hline & B & 240 & 84 \\
\hline \multirow[t]{2}{*}{ Nawule } & A & 225 & 53 \\
\hline & B & 247 & 75 \\
\hline \multirow[t]{2}{*}{ AB Bokazo } & A & 219 & 66 \\
\hline & B & 259 & 59 \\
\hline \multirow[t]{2}{*}{ Anwia } & A & 290 & 88 \\
\hline & B & 308 & 92 \\
\hline \multirow[t]{2}{*}{ Edwakpole } & A & 267 & 78 \\
\hline & $\mathrm{B}$ & 245 & 52 \\
\hline \multirow[t]{2}{*}{ Mean } & A & 249 & 66 \\
\hline & B & 260 & 70 \\
\hline $\operatorname{LSD}_{(0.05)}$ & & NS & NS \\
\hline
\end{tabular}


Figure 1: Correlation between assimilable $P$ in topsoil and $P$ leaf contents in coconut palms
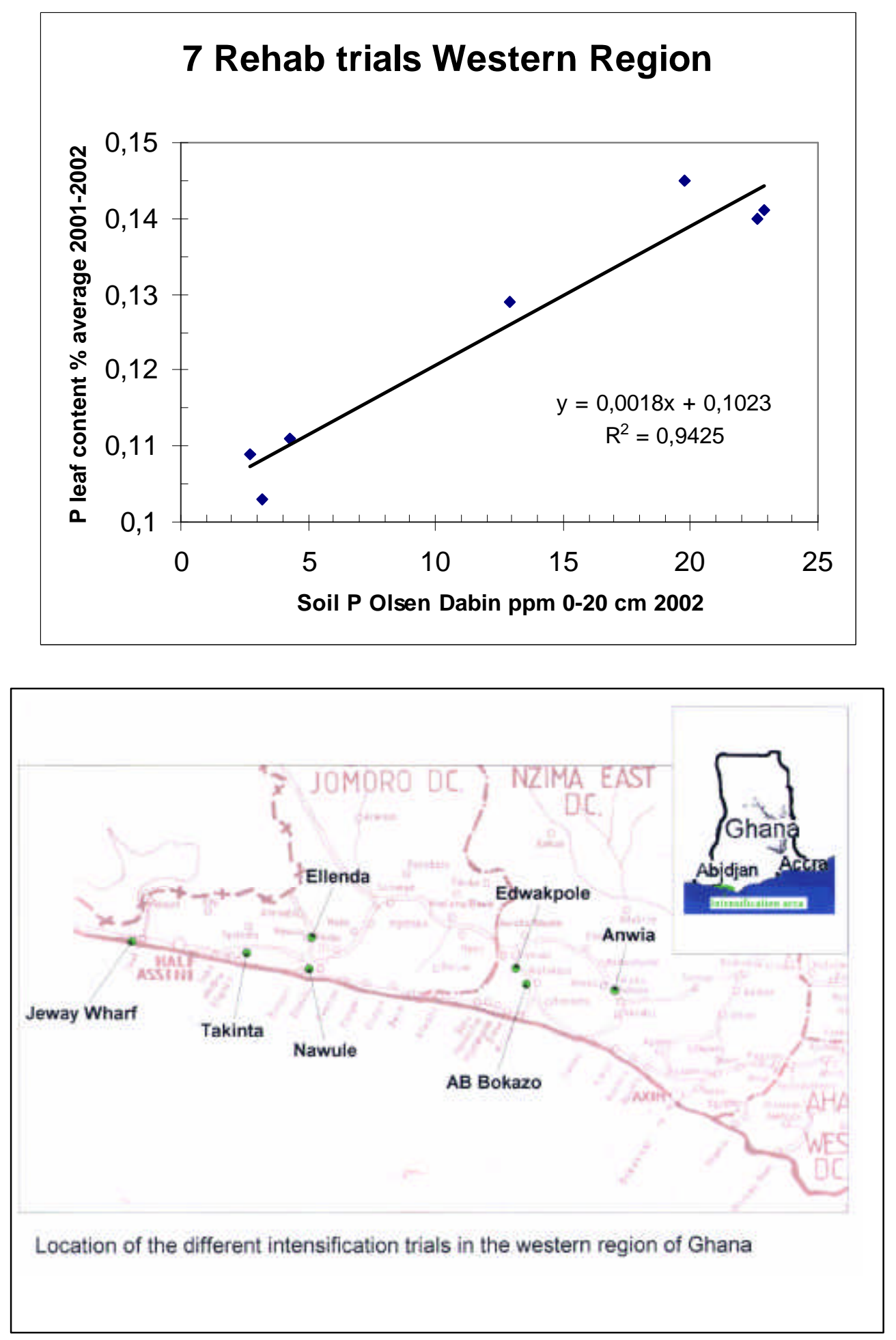